\title{
Reasons for food choices in nursing university students
}

\author{
Fernanda Carneiro Mussi*1, Caren Lorena Menezes Freitas ${ }^{2}$, Tássia Teles Santana de Macêdo ${ }^{3}$, Eliane Barbosa de \\ Souza $^{4}$, Alana de Souza Reis Carneiro ${ }^{5}$ \\ ${ }^{1}$ Escola de Enfermagem da Universidade Federal da Bahia, Salvador, BA, Brasil \\ ${ }^{2}$ Instituto Dante Pazzanese de Cardiologia. São Paulo, SP, Brasil \\ ${ }^{3}$ Escola Bahiana de Medicina e Saúde Pública, Salvador, BA, Brasil \\ ${ }^{4}$ Fundação Estatal Saúde da Família, Salvador, BA, Brasil \\ ${ }^{5}$ Hospital Santo Amaro, Salvador, BA, Brasil
}

Received: August 15, 2020

DOI: $10.5430 /$ jnep.v11n2p50
Accepted: September 30, $2020 \quad$ Online Published: October 25, 2020

URL: https://doi.org/10.5430/jnep.v11n2p50

\begin{abstract}
Background and objective: Food choice is a complex process that involves sensory and non-sensory characteristics, therefore, sociocultural, and psychological factors. The purpose of this study was to describe the reasons for food choices of nursing university students.

Methods: Cross-sectional study with 286 university students of the nursing course at a public university in Salvador/BA. Data were obtained by applying sociodemographic and academic life characterization instruments. The reasons for food choices were evaluated by the Food Choice Questionnaire (FCQ). The data were analyzed in percentages and the reasons for food choices by calculating the unweighted mean of each factor.

Results: There was a predominance of females (90.2\%), unmarried with partners (90.9\%), black race/color (87.8\%). and the mean age was 23.4 years old $(\mathrm{sd}=4.4)$. The majority of the students had semester load between 401 and 500 hours $(58.8 \%)$ and attended university in two or more shifts (80.4\%). Among the nine dimensions of the instrument, Sensory Appeal $(\bar{x}=3.35)$, Price $(\bar{x}=3.27)$ and Health $(\bar{x}=3.18)$ were the three most important for food choice. The familiarity and ethical concern factors were the least considered. Considering the FCQ items, the students chose the foods first because they were tasty $(\bar{x}=3.52)$, healthy $(\bar{x}$ $=3.47)$ and of good price $(\bar{x}=3.40)$.

Conclusions: For the students, the sensory appeal was the main reason for choosing food, being more relevant than price and health. Thus, there is need to consider the supply of healthy, attractive, and affordable foods in the university environment.
\end{abstract}

Key Words: Nursing students, Food preferences, Eating behavior

\section{INTRODUCTION}

Food consumption is determined by food choice, which constitutes a complex process that involves sociocultural, economic, psychological, and biological factors. ${ }^{[1-3]}$ Among these factors, there stand out visual presentation, flavor, nutritional value, forms of preparation, variety offered, cost of food, personal preferences, mood, stress, familiarity and ethical concerns. ${ }^{[4,5]}$ The process of food choice involves decisions based on conscious but also automatic, habitual and subconscious reflections. ${ }^{[6,7]}$ These considerations reinforce the question that the orientations in the area of food and nutrition based only on the health perspective seem to be limited. ${ }^{[8]}$

Valuing healthy food choice is important considering that

\footnotetext{
${ }^{*}$ Correspondence: Fernanda Carneiro Mussi; Email: femussi@uol.com.br; Address: Escola de Enfermagem da Universidade Federal da Bahia, Salvador, BA, Brasil.
} 
food is a protective factor for chronic non-communicable diseases, such as obesity, type 2 diabetes mellitus and systemic arterial hypertension. ${ }^{[3]}$ A diet characterized by excessive consumption of salt, saturated fat, sugary products and low regular intake of fruits, legumes and vegetables, if maintained in youth, may have repercussions on lifelong health. ${ }^{[9,10]}$

Entering academic life can influence and take to changes in food choices. In this period, students live new experiences and social relationships ${ }^{[6,11,12]}$ and many leave their parents homes and become responsible for managing their own diet. In addition, academic demands can lead to omission or replacement of main meals by quick snacks. ${ }^{[4,13]}$

Studies show that the diet of university students is characterized by the high consumption of foods rich in saturated fats, sugars and sodium and by the poverty of micronutrients. ${ }^{[14,15]}$ The preference for these foods is related to several factors such as the lack of time to prepare and make meals, the overlapping of academic activities, financial availability, the ease of food acquisition, the perception of the nutritional value of the food, among other factors. ${ }^{[12,16]}$

The study of eating behavior and the understanding of the main aspects that guide food choices can guide health education actions in the nutritional field, even if these aspects are complex, interact with each other and change over time. ${ }^{[17]}$ It is worth noting that the implementation of nutritional health education actions is one of the guidelines of the National Food and Nutrition Policy ${ }^{[18]}$ and also an important recommendation of the World Health Organization. ${ }^{[9]}$ The educational interventions performed by nurses need to consider the reasons for food choices and the literature is scarce on the subject in nursing university students. ${ }^{[19]}$

Based on the above, the objective of this study was to describe the reasons for food choices of nursing university students.

\section{METHOD}

\subsection{Design and participants}

The cross-sectional study was conducted with nursing students from a public institution in the city of Salvador, Bahia, Brazil. There were included university nursing students registered among the first and tenth semester of the program, with a minimum age of 18 years, of both sexes. There was exclusion of those who took a time off or were studying abroad.

In 2016, the period of data collection, 353 students were registered in the nursing program according to the Graduate Course Collegiate. The number of nursing students registered in each semester was: 48 in the first, 39 in the second,
18 in the third, 32 in the fourth, 34 in the fifth, 34 in the sixth, 39 in the seventh, 29 in the eighth, 36 in the ninth, and 44 in the tenth semesters. Of the 353 university students, 65 did not agree to participate in the research and two students were taking a time off the course. Thus, 286 were the students of access of this research.

\subsection{Procedures}

Data collection occurred in the classroom, where the students were contacted by the researchers and invited to participate in the investigation. The data collection began after explanation about the research objectives, risks, and benefits of the research. Also, it was ensuring anonymity, autonomy for students to give up research at any stage. Then, after reading and signing the Informed Consent Form in 2 (two) copies the student answered the questionnaires.

\subsection{Measures}

Data collection used an instrument on sociodemographic data and characterization of academic life, consisting of closed and semi-structured questions. The Food Choice Questionnaire $(F C Q)^{[1,8]}$ was applied to raise the reasons for the food choices. The original version of the FCQ comprises 36 items that represent food attributes, intrinsic and extrinsic, which can motivate consumers in the food choice. Each item allows classifying the relevance of food choice on a given day, using a 4-point scale ( 1 = not important, 2 = little important, $3=$ moderately important, 4 = very important). The questionnaire measures nine motivational dimensions, each of which includes three to six items. These dimensions are: Health; Mood; Convenience; Sensory appeal; Natural content; Price; Weight Control; Familiarity and ethical concerns. ${ }^{[2]}$

\subsection{Data analysis}

The data were analized using the software Statistical Package for the Social Science, version 22.0 of the Windows platform. Categorical variables were analyzed as absolute (n) and relative $(\%)$ frequencies, and quantitative variables, as means and standard deviation. The FCQ analysis was done by factor. The values assigned by the participants to each factor item were summed. The value obtained was divided by the number of items of each factor and, finally, this value was divided by the total number of participants. Higher scores indicate that the participant attributed greater importance to a given factor.

\subsection{Ethical considerations}

The present work was approved by the Ethics Committee at the Nursing School of the Federal University of Bahia. Opinion n. 353.038. Ethical principles were respected in accordance with Resolution n. 466 of December 12, 2012, [20] 
of the National Health Council. This research is part of the matrix project named "Cardiovascular risk factors in nursing undergraduates: implications for health care".

\section{Results}

\subsection{Sociodemographic and academic characterization}

Regarding the sociodemographic characteristics, there was a predominance of female university students (90.2\%), unmarried with partners $(90.9 \%)$, and black race/color $(87.8 \%)$ The mean age was 23.4 years $(\mathrm{SD}=4.4)$. The majority lived with two or three people (55.6\%), had inactive employment status $(82.2 \%)$, monthly family income of 3 to 5 minimum remunerations $(44.1 \%)$ and considered the income unsatisfactory for the own sustenance $(65.0 \%)$.

Concerning the characteristics of academic life, most were attending the sixth to tenth semester $(54.5 \%)$, had a semester load between 401 and 500 hours (58.8\%), attended university in two or more shifts $(80.4 \%)$, and attended four or more subjects $(67.5 \%)$.

\subsection{Food choice characterization}

Table 1 presents the nine factors of the FCQ according to the means obtained, revealing that the food choices of university students were predominantly related to sensory appeal, price, and health. The factors Familiarity and Ethical Concern were the reasons less considered in food choices.

Table 1. Classification of factors that motivate the food choice of nursing university students. Salvador/BA, 2019

\begin{tabular}{ll}
\hline Factors & Mean \\
\hline Factor 4 - Sensory appeal & 3.35 \\
Factor 6 - Price & 3.27 \\
Factor 1 - Health & 3.18 \\
Factor 3 - Convenience & 2.93 \\
Factor 5 - Natural content & 2.85 \\
Factor 2 - Humor & 2.84 \\
Factor 7 - Weight control & 2.70 \\
Factor 8 - Familiarity & 2.37 \\
Factor 9 - Ethical concern & 1.91 \\
\hline
\end{tabular}

Source: Research data

Table 2 shows the average obtained for the 36 FCQ items. In the food choice, the students considered more important the food to be tasty $(\bar{x}=3.52)$, to keep healthy $(\bar{x}=3.47)$, to have a fair price $(\bar{x}=340)$, being nourishing $(\bar{x}=3.37)$, having a good smell $(\bar{x}=3.31)$ and a good appearance $(\bar{x}$ $=3.30$ ). The reasons that least interfered in the food choice were to be similar to the food eaten as a child $(\bar{x}=1.88)$, to be from countries that approve the way they are produced ( $\bar{x}$ $=1.80$ ) and clearly showing the identification of the country of origin $(\bar{x}=1.78)$.

\section{Discussion}

In the studied group, women predominated, which has been observed in other studies in this area of education. ${ }^{[21,22]}$ The young adult prevalent in the study coincides with the age group of admission to the University, as well as the predominance of the unmarried may be related to the student's phase of life, when they are busy with professional training and in the identification phase of future partners. ${ }^{[13,23]}$ The inactive work situation was more frequent and was expected considering that the course demands activities in two shifts, hindering employment. ${ }^{[23]}$

These characteristics of university students corroborate other studies with students from other nursing graduate courses. ${ }^{[13,19,24]}$ There was a higher proportion of selfreported black race/color, which is related to the study being conducted in Salvador, Bahia, a city where Afro-descendants predominate according to data from the 2010 Demographic Census. ${ }^{[14]}$ The average monthly family income is equivalent to middle-class families and has been identified in previous studies with nursing students in Salvador. ${ }^{[13]}$

Considering that the predominantly studied course load was from 401 to 500 hours and that most students attended school in two or more shifts, the course seems to require full dedication, thus, snacks and meals were made at the School or in its surroundings. The greatest motivation for food choice fell on the sensory appeal, expressing that food is not only a means of energy release, but also a source of pleasure. ${ }^{[11]}$ Many sensations are involved during food intake. The sensations of taste, aroma, appearance and consistency influence food choice and the palate is a sense exercised in the act of eating. In this research, for students, foods should be first delicious, should have a good smell and a good appearance, which corroborates the study by Januszewska, Pieniak and Verbeke (2011) which showed that Europeans considered the sensory appeal of food the most important factor in their choice. ${ }^{[24]}$

The study also showed that price was an important factor for food choice, which was an expected result as most participants did not work and reported that income was insufficient for their own sustenance. Income can determine food choices, stressing that healthy diets, characterized by higher consumption of fruits, vegetables, whole grains, and lean meats are more expensive than diets characteristic of the Western pattern, rich in fatty and sweet foods. ${ }^{[1,19]}$

Health was the third factor most cited by university students, which may have been strongly influenced by academic education in a course in the health area, nursing. During graduation, university students could know the importance of a balanced diet in the prevention of chronic diseases and complications and discuss its health benefits. Food is essential to life and 
health and, for students, healthy, nourishing, and fair-priced Filipinos, the most important factors were health and price. ${ }^{[?]}$ food is important, corroborating another study, in which, for

Table 2. Classification of items that motivate food choice of nursing university students. Salvador/BA, 2019

\begin{tabular}{|c|c|c|}
\hline Factors & Items that motivate food choice & Mean \\
\hline Factor 4 - Sensory appeal & Be tasty & 3.52 \\
\hline Factor 1 - Health & Keep me healthy & 3.47 \\
\hline Factor 6 - Price & A fair price & 3.40 \\
\hline Factor 1 - Health & Be nourishing & 3.37 \\
\hline Factor 4 - Sensory appeal & Have a good smell & 3.31 \\
\hline Factor 4 - Sensory appeal & Look good & 3.30 \\
\hline Factor 1 - Health & Contains a lot of vitamins and minerals & 3.26 \\
\hline Factor 4 - Sensory appeal & Have a nice texture & 3.25 \\
\hline Factor 6 - Price & Not expensive & 3.26 \\
\hline Factor 2 - Mood & Make me feel good & 3.19 \\
\hline Factor 6 - Price & Be cheap & 3.16 \\
\hline Factor 1 - Health & Be rich in fiber and give me satiety & 3.10 \\
\hline Factor 3 - Convenience & Be easy to prepare & 3.03 \\
\hline Factor 7 - Weight control & Have little fat & 3.00 \\
\hline Factor 1 - Health & Be good for my skin/teeth/hair/nails etc. & 2.99 \\
\hline Factor 3 - Convenience & Be easy to find in grocery stores and supermarkets & 2.98 \\
\hline Factor 5 - Natural content & Contain natural ingredients & 2.98 \\
\hline Factor 3 - Convenience & Can be cooked very simply & 2.90 \\
\hline Factor 3 - Convenience & Do not take too long to prepare & 2.90 \\
\hline Factor 5 - Natural content & Do not contain additives/pesticides & 2.88 \\
\hline Factor 1 - Health & Rich in protein & 2.86 \\
\hline Factor 2 - Mood & Make me happy/excited & 2.84 \\
\hline Factor 2 - Mood & Help me relax & 2.82 \\
\hline Factor 2 - Mood & Help me deal with stress & 2.82 \\
\hline Factor 3 - Convenience & Can be purchased from nearby locations & 2.82 \\
\hline Factor 2 - Mood & Help me deal with life & 2.72 \\
\hline Factor 5 - Natural content & Do not contain artificial ingredients & 2.70 \\
\hline Factor 8 - Family & Commonly eaten & 2.65 \\
\hline Factor 2 - Mood & Keep me awake/alert & 2.63 \\
\hline Factor 7 - Weight control & Help me control my weight & 2.63 \\
\hline Factor 8 - Family & Be familiar & 2.60 \\
\hline Factor 7 - Weight control & Have low calories & 2.47 \\
\hline Factor 9 - Ethical concern & Be environmentally friendly packaged & 2.15 \\
\hline Factor 8 - Family & Be like the food I used to eat as a child & 1.88 \\
\hline Factor 9 - Ethical concern & Come from countries that approve the way they are produced & 1.80 \\
\hline Factor 9 - Ethical concern & Clearly show the identification of the country of origin & 1.78 \\
\hline
\end{tabular}

Source: Research data

The factors Sensory Appeal, Price and Health were the most cited in this study and coincide with those most mentioned in another study that examined similarities and differences in food choice between American and Chinese university students, which demonstrates that, although students live in countries with different cultures, they presented similar behavior in food choice..$^{[5,19]}$

Convenience was the fourth factor with the highest average in food choice. This factor may be associated with academic demands, mainly due to the extensive course load and activities developed during nursing education. Many students claimed to remain more than two shifts at the university. This scenario can influence the quality of food choice, as well as the time to perform the main meals. ${ }^{[4]}$ They often have little time for meals, which are replaced by quick snacks with low nutritional quality or may even omission. ${ }^{[16]}$ This factor indicates the importance of the university providing places with easy access to healthy, attractive foods at a viable cost 
in the university environment. ${ }^{[6,11]}$

Family eating behavior provides the environment that shapes the child's acceptance patterns ${ }^{[9]}$ and can influence food choices. However, in this study, the choice of foods like those eaten as a child was not so expressive, possibly due to unpleasant experiences, change of taste and interaction and discovery of new foods and forms of preparation more appropriate to personal preferences.

The concern about the origin of food is essential to know how food is produced, whether pesticides are present, whether it contains preservatives or substances that can interfere with its quality and bring health risks. ${ }^{[10]}$ Despite the importance of these characteristics, students still need to mature this ethical responsibility for choosing the foods ingested, because the items related to the clear description of the origin and form of food preparation were the least mentioned, corroborating the study by Januszewska, Pieniak and Verbeke (2011). ${ }^{[24]}$

The results obtained can serve as an incentive to the implementation of public and university internal policies stimulating and offering healthy, attractive, affordable food in the university environment, to ensure a pleasurable, prudent, and healthy consumption. They offer subsidies for the construction of easily accessible spaces that add to the motivation for food choice, in addition to contributing to the reflection with the university students on the reasons linked to food choices.

\section{Conclusion}

The present study showed that the three most important factors in food choice of university students were Sensory Appeal, followed by Health and Price. Considering the impact of eating behavior on health, there is need to consider the supply of healthy, attractive, and affordable foods in the university environment. There is also needed to awaken ethical awareness in the food choice of university students.

\section{FUNDING STATEMENT}

This study was funded by the National Council for Scientific and Technological Development (CNPQ)-Process 310842/2018-2.

\section{ACKNOWLEDGEMENTS}

Authors thank the School of Nursing at the Federal University of Bahia (UFBA), the Interdisciplinary Group on Cardiovascular Health Care (GISC), and the National Council for Scientific and Technological Development (CNPq) by the support the matrix project coordinated by Dr. Fernanda C. Mussi.

\section{Conflicts OF InTEREST Disclosure}

No conflict of interest has been declared by the authors.

\section{REFERENCES}

[1] Cabral D, de Almeida MDV, Cunha LM. Food Choice Questionnaire in an African country - Application and validation in Cape Verde. Food Quality and Preference. 2017; 62(July): 90-95. https: //doi.org/10.1016/j.foodqual.2017.06.020

[2] Heitor SFD, Estima CCP, Das Neves FJ, et al. Tradução e adaptação cultural do questionário sobre motivo das escolhas alimentares (Food Choice Questionnaire - FCQ) para a língua portuguesa. Ciencia e Saude Coletiva. 2015; 20(8): 2339-2346. PMid:26221799 https://doi.org/10.1590/1413-81232015208.15842014

[3] Marconato MSF, Silva GMM, Frasson TZ. Habito alimentar de universitários iniciantes e concluintes do curso de nutrição de uma universidade do interior paulista. Revista Brasileira de Obesidade, Nutrição e Emagrecimento. 2016; 2(12): 588-596.

[4] Beaudry KM, Ludwa IA, Thomas AM, et al. First-year university is associated with greater body weight, body composition and adverse dietary changes in males than females. PLoS ONE. 2019; 14(7): 1-19. PMid:31269047 https://doi.org/10.1371/journal.pone.0 218554

[5] Pearcey SM, Zhan GQ. A comparative study of American and Chinese college students' motives for food choice. Appetite. 2018; 123: 325-333. PMid:29337255 https://doi .org/10.1016/j . appet. 2018.01 .011

[6] Jakubowska D, Radzymińska M. Health and environmental attitudes and values in food choices: a comparative study for Poland and
Czech Republic. Oeconomia Copernicana. 2019; 10(3): 433-452. https://doi.org/10.24136/oc.2019.021

[7] Michels N, Man T, Vinck B, et al. Dietary changes and its psychosocial moderators during the university examination period. European Journal of Nutrition. 2020; 59(1): 273-286. PMid:30684033 https://doi.org/10.1007/s00394-019-01906-9

[8] Shepherd R. Social determinants of food choice. Proceedings of the Nutrition Society. 1999; 58(4): 807-812. PMid:10817147 https: //doi.org/10.1017/S0029665199001093

[9] WHO. Guideline: Sugars intake for adults and children. World Health Organization. 2018; 57(6): 1716-1722.

[10] Brasil. Guia Alimentar para a População Brasileira. Secretaria de Atenção à Saúde. Departamento de Atenção Básica. 2014; 156. http://bvsms. saude.gov.br/bvs/publicacoes/guia_ alimentar_populacao_brasileira_2ed.pdf

[11] Roy R, Soo D, Conroy D, et al. Exploring University Food Environment and On-Campus Food Purchasing Behaviors, Preferences, and Opinions. Journal of Nutrition Education and Behavior. 2019; 51(7): 865-875. PMid:30981657 https://doi.org/10.1016/j. jneb.2019.03.003

[12] Carneiro M, de N, de L, et al. Association between dietary habits and nutritional status in college students. Rev Soc Bras Clin Med. 2017; 14(2): 84-88.

[13] Macedo TTS, de Mussi FC, Geovana C, et al. Perfil alimentar, clínico e padrão de atividade física em ingressantes universitários de 
enfermagem. Revista Cubana de Enfermería. 2019; 1(25): 2-21.

[14] IBGE. Pesquisa de orçamentos familiares 2008-2009: análise do consumo alimentar pessoal no Brasil. Instituto Brasileiro de Geografia e Estatística. (Vol. 39). Rio de Janeiro. 2011.

[15] Santos MC, Angarten VG, Munaro HLR, et al. Associação do excesso de peso com variáveis demográficas e atividade física no lazer em universitários. Revista Brasileira Ciência e Movimento. 2014; 22(3): 14-19. https://doi.org/10.18511/0103-1716/ rbcm.v22n3p14-19

[16] Duarte FM, De Almeida SDS, Martins KA. Alimentação fora do domicílio de universitários de alguns cursos da ârea da saúde de uma instituição privada. O Mundo Da Saude. 2013; 37(3): 288-298. https://doi.org/10.15343/0104-7809.2013373288298

[17] Navarro-Prado S, González-Jimenez E, Montero-Alonso M, et al. Estilo de vida y seguimiento de la ingesta dietética en estudiantes del Campus de la Universidad de Granada en Melilla. Nutricion Hospitalaria. 2015; 31(6): 2651-2659. https://doi .org/10.3305/nh.2 015.31 .6 .8973

[18] Brasil. Política Nacional de Alimentação e Nutrição. Secretaria de Atenção à Saúde. Departamento de Atenção Básica. Brasília. 2013. http://bvsms. saude.gov.br/bvs/publicaco es/politica_nacional_alimentacao_nutricao.pdf

[19] Navarro González I, Ros G, Martínez-García B, et al. Adherencia a la dieta mediterránea y su relación con la calidad del desayuno en estudiantes de la Universidad de Murcia. Nutricion Hospitalaria. 2016; 33(4): 901-908. PMid:27571665 https://doi.org/10.2 0960/nh.390

[20] Brasil. Resolução no 466, de 12 de dezembro de 2012. Diário Oficial Da União. 2012. Available from: http://conselho. saude.gov .br/resolucoes/2012/Reso466.pdf

[21] Gonçalves A, Cabral L, Silva D, et al. Insónia nos estudantes de enfermagem em ensino clínico. Revista Portuguesa de Enfermagem de Saúde Mental. 2016; 3(Spe. 3): 73-78. https ://doi .org/10.1 9131/rpesm. 0121

[22] Barbosa RR, Martins MCG, Carmo FPT, et al. Estudo sobre estilos de vida e níveis de estresse em estudantes de medicina. Int. j. Cardiovasc. Sci. (Impr.). 2015; 28(4): 313-319. https : //doi.org/10.5935/ 2359-4802. 20150045

[23] Brito BJQ, Gordia AP, Quadros TMB. Estilo de vida de estudantes universitários: Estudo de acompanhamento durante os dois primeiros anos do curso de graduação. Medicina (Brazil). 2016; 49(4): 293-302. https://doi.org/10.11606/issn.2176-726 2.v49i4p293-302

[24] Januszewska R, Pieniak Z, Verbeke W. Food choice questionnaire revisited in four countries. Does it still measure the same? Appetite 2011; 57(1): 94-98. PMid:21477629 https://doi .org/10.101 6/j.appet.2011.03.014 